\title{
Disease Stigma in the Archaeological Record: A Review of Current Research
}

\author{
Maryann Scott*
}

\begin{abstract}
Stigma has been and continues to be reality for many individuals affected by disease. For bioarchaeologists, the study of disease stigma in the past often is limited to the examination of mortuary treatment of individuals exhibiting skeletal evidence of disease. This paper examines some of the research dealing with the mortuary treatment of individuals showing characteristics of leprosy. While some studies present examples of differences in manner and place of burial, others suggest that affected individuals were treated no differently in death than those showing no skeletal evidence of disease.
\end{abstract}

Keywords: Bioarchaeology, paleopathology, leprosy, mortuary treatment

Today, social exclusion and stigma are integral to the experience of disease for many affected individuals throughout the world. Both discrimination from others and the internalization of those attitudes influence how individuals suffering from disease perceive their place in society, and whether the individuals are seen as having a place in society at all (Hubert, 2000; de Groot et al., 2011). Stigma manifests in the segregation of diseased individuals from the community, social isolation for them and their families, and restrictions on movement and habitation. (Hyland, 2000). Disease-associated stigma is by no means a modern phenomenon; often, the assumption is that such views were even more common in the past due to a lack of understanding of disease aetiology and processes (Hyland, 2000).

In bioarchaeology, knowledge of past disease processes and experiences comes from the excavation and examination of human remains. While mortuary behaviour associated with status, gender, and ethnicity has been reasonably well defined, less attention has been paid to the concept of mortuary treatment as the archaeological manifestation of stigma associated with disease. This paper will review literature dealing with differential mortuary treatment of those exhibiting disease traits, and the changing views around disease stigma in the past. The research in this particular field has necessarily focused on diseases that leave bone evidence, conducive to making a plausible diagnosis of the individual's condition at death. Leprosy, which was widespread in Europe for hundreds of years, may leave diagnostic bone lesions and is also strongly associated with stigma (Brenner, 2010). As a consequence, this disease is one of the more common conditions dealt with in current literature, and will constitute much of the information contained in this paper. In spite of the stigma that sufferers of leprosy and other diseases may have experienced in their lives, there is persuasive evidence that mortuary behaviour did not reflect exclusion or differential treatment.

Goffman (1963) defines stigma as the possession of an attribute, whether a physical blemish (visible disabilities and diseases); blemish of individual character (undesirable behaviours, personality traits, or beliefs); or tribal affiliation (race and religion), which causes others to view one as a "tainted, discounted" person (Goffman, 1963:3). While

\footnotetext{
*Department of Archeology \& Anthropology, College of Arts and Science, University of Saskatchewan, Saskatoon, SK, Canada Correspondence: mes133@mail.usask.ca 
Goffman uses attribute-related language to describe stigma, he notes that relational language might be more appropriate. The experience of stigma is wholly interpersonal and situational in nature; the same individual may experience stigmatization in one situation but not in another (Goffman, 1963).

Since Goffman's seminal work on stigma, researchers have not only expanded upon and refined the concept, but have also studied its application in a number of different disciplines and fields. In their analysis of varying definitions of stigma and prejudice, Phelan et al. (2008) delineate a number of common themes. Many definitions of stigma include both the maintenance of social domination and power, and the preservation and enforcement of social norms. Individuals seen as constituting a threat to either established power or accepted norms are stigmatized, thereby further normalizing the status quo and providing a cautionary example to those who might consider deviating in the future (Phelan et al., 2008). A third broad theme arising from the researchers' analysis is the desire to avoid illness. In reviewing the myriad studies published on disease stigma, researchers looked to evolutionary psychology to explain the phenomenon. In the distant past, people with physical or behavioural anomalies, or such overt signs of illness as coughing and skin lesions, were to be avoided in order to prevent both immediate infection and the propagation of 'sickly' attributes to one's offspring. Modern humans are the descendants of those who were most successful in avoiding contact with their ill compatriots; in many ways, humans are psychologically conditioned to avoid or shun anyone who appears 'abnormal' (Phelan et al., 2008).

While Goffman's (1963) characterization of stigma focuses on interpersonal relationships, Corrigan and Fong (2014) place the interpersonal experience of stigma within the larger socio-cultural sphere of structural stigma. Structural stigma includes both formal expressions of stigma (for example, laws restricting the parental rights of the mentally ill) and informal ones (such as social exclusion, resulting in a reluctance to seek treatment and risk being labelled). Reidpath et al. (2005) claim that stigmatization is related to group membership; in other words, the group enacts deeply engrained rules about who should be a group member and thus able to benefit from shared resources. Pescosolido et al. (2008) also recognize that interpersonal interactions take place within the realm of structural or institutionalized ideas of what constitutes normal and valuable. Ultimately, both norms and stigma are socially constructed (Pescosolido et al., 2008).

The social constructs of stigma and exclusion are tied to the social construct of any given disease and to those viewed as suffering from or infected with the disease. As Conrad and Barker (2010) note, the characterization of disease goes far beyond the medical diagnosis of 'not well' or functioning abnormally. The social construction of illness involves the ascribed meaning of disease. Currently, certain diseases have particular connotations, depending on the culture: evil or an enemy to be fought (cancer); repayment for past behaviour (lung or liver disease); or purely psychosomatic (chronic fatigue syndrome and many allergies) (Conrad and Barker, 2010). An individual's experience of disease is related as much to the social response to that disease as it is to its symptoms and effects. The researchers present several examples of studies of modern individuals facing stigmatized illnesses, such as epilepsy, HIV/AIDS, and mental illness; in many cases, respondents stated that the stigma associated with their conditions was more difficult to manage than the symptoms of the disease itself.

The examination of mortuary treatment as related to disease and potential disease stigma is fraught with the same issues and subject to the same cautions as any other burial/skeletal remains analysis. As Wood et al. (1992) note, a disease may not be evident in skeletal remains, even if it was present in an individual at the time of death. If a different type of mortuary treatment is observed, it is challenging to make the case that the treatment is related to the condition at death rather than position or status in life. Therefore, studies attempting to link mortuary treatment to disease stigma are by necessity limited to diseases that may affect bone growth or morphology, and further are limited to individual cases demonstrating those characteristic bone changes. In general, the mortuary treatments observed in such studies fall into two main categories: location of burial and manner of burial.

Crawford (2010) finds no evidence in Anglo-Saxon documentation to suggest that disease or disability alone would lead to a difference in the typical interment pattern. In her review of excavated Anglo-Saxon era cemeteries, Hadley (2010) notes that although uncommon, there were instances of physically different individuals receiving alternative mortuary treatment. Several examples of this involve the liminal burials, i.e., burials at a cemetery's boundaries, of adult males who showed evidence of either a specific disease, or a condition that, in life, would have manifested itself physically. In one Northamptonshire cemetery, a male showing signs of leprosy and another two men with atrophied and shortened limbs were buried apart from others, near the churchyard boundary. A similar pattern was noticed at another location, wherein an individual with collapsed vertebrae, possibly due to spinal tuberculosis, was buried near the cemetery limits along with three other men. In these particular instances, the individuals at the cemetery's edge were the only physically distinct remains excavated. Examples of 'set apart' burials from other cemeteries include another individual with evidence of leprosy and others whose injuries suggested a violent death (Hadley, 2010). 
By far the largest body of research on disease stigma and social exclusion centres on leprosy, both past and present. Caused by an infection of Mycobacterium leprae, the disease causes skin lesions, neuropathy in the affected regions, and eventual bone and tissue necrosis in the extremities (Aufderheide and Rodriguéz-Martin, 1998:141-146). Still endemic to many parts of the world today, leprosy was common in medieval Europe to the late 1500s, at which point its incidence declined significantly (Roberts, 2011).

Leprosy is one of the few diseases documented throughout history wherein those suffering from the disease were set apart from the rest of the population in life and in death. Brenner (2010) notes various historians who attest that the exclusion of lepers was a societal norm. Leprosaria (leper hospitals) were common in medieval Western Europe; over 300 documented hospitals were present in England alone (Roffey, 2012). Leper hospitals were constructed and endowed by wealthy patrons as part of their salvation-driven charitable works. Current research and reviews of historical documents suggest that these were institutions of seclusion and palliative care, rather than of exclusion and isolation (Roffey, 2012). While located outside of the city or town limits, leper hospitals tended to be on main roads to better attract donations from passersby or pilgrims (Brenner, 2010).

Archaeological evidence also supports the idea that while leprosy sufferers were set apart spatially by their residence in a leper hospital, they were not necessarily isolated from society. A number of the many known leprosaria in England have been excavated in recent years, contributing to a more accurate view of who lived and died in such institutions. Roffey and Tucker (2012) discuss the northern cemetery at St. Mary Magdalen, Winchester, which was in operation as a leper hospital since the 11th century. Eighty four percent $(84 \%)$ of the individuals (including a number of children) excavated from that cemetery showed skeletal evidence of leprosy, in contrast with lower percentages from excavations at other leper hospitals (Roffey and Tucker, 2012). The cemetery itself was well laid out and organized, with little evidence of cross-cutting, indicating that the graves had likely been marked. The grave cuts were anthropomorphic in shape, with niches for the shoulders and head; this style of grave cut in the medieval era is usually associated with highranking ecclesiastical burials. Overall, the graves indicate that the individuals therein were treated with care and respect in death, likely mirroring the treatment received at the leper hospital in life (Roffey and Tucker, 2012).

Of course, not every person with leprosy was admitted to a leper hospital or was buried in a cemetery associated with one. Most of the known English cases of leprosy have been found in remains excavated from 'ordinary' cemeteries. Roberts (2011) notes one example of a liminal burial within this group; the rest occur within the normal bounds of the cemetery. A study by Linderholm and Kjellström (2011) presents Swedish evidence of liminal burials. At the time, Swedish burial laws designated this location as the appropriate burial spot for outcasts or individuals from a different area. In one particular cemetery, six individuals exhibiting bone lesions consistent with leprosy were excavated from the outskirts. Stable isotope analysis indicated that these six individuals were not from a different location, and were neither more nor less nutritionally disadvantaged than others in the same burial location. On the surface, it would appear that burial on the outskirts as an outcast may have had more to do with social status than disease status (Linderholm and Kjellström, 2011). The authors caution, however, that the unlesioned individuals found may also have been ill, so the burial location may in fact be related to disease stigma.

As mentioned previously, the other mortuary difference most easily observable in archaeological work is the manner of burial. Hadley (2010) relates several AngloSaxon examples of prone, rather than supine, interments. Everything else about these burials was consistent with usual funerary rituals, and there was no skeletal evidence of disease or violence; one can only speculate as to the reasons behind the altered body position. Hadley's sole example of an altered burial seemingly linked to a physical condition was that of a male whose enlarged proximal tibia meant that straightening his leg would have been difficult or impossible. Stones were placed under the affected knee, serving as a support and brace.

A study by Little and Papadopoulos (1998) reports an unusual manner of burial from 900-850 B.C.E., near Athens. In spite of the presence of nearby contemporaneous cemeteries, a man was deliberately and carefully buried in the upper fill of a well. During his life, this individual had sustained significant head trauma, as well as compression fractures to the lumbar vertebrae. The latter injuries, with accompanying osteoarthritis, likely rendered him noticeably physically impaired. In addition, Little and Papadopolous (1998) believe it is unlikely that the individual healed from the head trauma without some neurological affects. This appears to be a case in which someone who was visibly disabled, and may not have spoken, perceived, or behaved in a manner considered 'normal,' was buried in a manner and location different from that of others of the same era. There is earlier evidence of Greek well burials, but remains excavated from these sites appear to have no correlation with disease or disability (Papadopolous, 2000).

Two examples of unusual burials thought to be clearly linked to the disease status of the deceased come from Peru and Japan. In the Peruvian example, Klaus and Ortner (2014) describe the case of an elderly indigenous woman, whose lifetime spanned the transition between the pre-contact and early Spanish colonial eras. Her bones 
displayed the caries sicca and bone formation pattern consistent with tertiary treponemal disease. In contrast to the other excavated burials in the early colonial cemetery, this individual was buried at least $2 \mathrm{~m}$ deeper, but could not have pre-dated the establishment of the cemetery. Other burials followed the European traditions of supine position and placement in a coffin or shroud. The elderly female appears to have been placed haphazardly into the grave, with her burial shroud bunched around her chest and legs (Klaus and Ortner, 2014). The authors believe that the differential burial is no coincidence. The individual would have been infected for a number of years; each of the bone lesions would have had a corresponding skin lesion, resulting in significant physical disfigurement. With other burials, the mortuary preparation involved physical contact with the deceased (arranging limbs, wrapping a shroud, etc.); this individual seems to have been interred with a minimum of physical contact (Klaus and Ortner, 2014).

In Japan, the 15th-18th century Nabe-kaburi (HeadCovered with Iron Pots) burials have long been a source of mystery and interest (Suzuki et al., 2014). As the translation of the Japanese term suggests, the dead were buried with iron pots or mortars covering their heads. Lesions consistent with leprosy and syphilis have been found on a number of the 105 burials excavated thus far, consistent with one oral tradition that suggests that the pots were intended to prevent infection spreading to the surviving community. Suzuki et al. (2014) were able to detect $M$. leprae DNA in two skeletal samples, thereby supporting the link between disease and this mortuary style. The researchers suggest that because the leprosy sufferers were able to live long enough with the disease for bone lesions to occur, they were well integrated with and cared for by their communities. The iron pots, therefore, may have had a nuance of protection of the deceased, rather than protection for the living. Suzuki et al. (2014) propose that the Nabe-kaburi burials may have been performed for anyone dying 'unnaturally'.

While the preceding examples suggest a correlation between disease and mortuary treatment, there are numerous instances of diseased individuals receiving the same funerary treatment as other deceased. Craig and Craig (2011) report the example of an Anglo Saxon child with apparent fibrous dysplasia. This condition would have resulted in obvious facial asymmetry and deformity, as well as potential speech issues. As Crawford (2010) states, both visible disfigurement and difficulty with speech resulted in a greater perception of disability and deviance in the AngloSaxon world. However, the child's burial was no different from others excavated, indicating that whatever the child's status in life may have been, the child's status in death was unaffected (Craig and Craig, 2011).

In contrast to the Peruvian treponema burial discussed earlier, Marsteller et al. (2011) found no divergence in the mortuary treatment of six women with evidence of leishmaniasis. This is a disfiguring endemic disease, causing cutaneous lesions and, potentially, destruction of the nasal and palatine bones. The disease, which still exists today, is the object of great stigma, and so researchers were curious to see if that attitude would be borne out in pre-European contact mortuary treatment. Their study found no apparent differences between the six individuals who exhibited obvious lesions and those nonlesioned dead nearby.

Several examples exist of leprosy receiving no extraordinary treatment. Blau and Yagodin (2005) report an extremely early (80-240 C.E.) example of leprosy from an area that is now part of Uzbekistan. The infected woman was buried with a young child, possibly her own, in the same manner as 14 other individuals excavated from the same cemetery. A similar pattern is true for a young woman excavated from a 15th century burial in Cyprus (Baker and Bolhofner, 2014). Although her remains showed definite signs of the rhinomaxillary syndrome associated with lepromatous leprosy, she was buried within the basilica, indicating that she was considered a member of the church community. In addition, wear on her remaining maxillary incisor suggests that she was actively involved in sewing, weaving, or lace making, indicating that if there was stigma, she was able to overcome it. Roberts (2011) suggests that the move to isolate and segregate disease sufferers was a largely Victorian phenomenon. This may be the case, but was not evident in Walker's (2009) case study of a young man showing skeletal lesions associated with leprosy. The individual was buried before 1851 in St. Marylebone Cemetery in London, by that time a preferred cemetery of the elite. His remains indicate that he received medical care (including the amputation of an affected limb). His burial alongside others of his probable status shows no segregation in death (Walker, 2009).

As in any archaeological work, it is problematic to accurately ascribe meaning to sociocultural elements such as mortuary treatment. Even when faced with an obvious example of differential treatment, it is rarely possible to state decisively whether that treatment was due to the individual's status in life, manner or cause of death, or simply circumstances or need for expediency. As noted in the research discussed here, there is evidence that disease and associated stigma influenced mortuary treatment. However, for every example of this type, there are many examples of identical mortuary treatment for all members of the cemetery community. It appears that whatever stigma may have existed, and however individuals with a disease were treated in life, death was the great equalizer. This may reflect a tangible manifestation of some of the previously mentioned stigma theory. On a sociocultural level, there may have been structural stigma; in such cases as leprosy, there is significant evidence of both official and 
informal stigma. On an interpersonal level, however, evidence of stigma is more nebulous, and depends greatly on each relationship and the individuals involved.

One of the goals of modern paleopathology is to examine the health of past populations, and this work necessarily includes the study of the social construct of disease in the past, including stigma and social exclusion. While knowledge of societal and population attitudes is important, it is vital to remember that disease-stricken individuals in the past were often buried in their home communities, by and close to their families and neighbours. In other words, we are observing mortuary treatment of individuals by the people who knew them. The mortuary treatment does not necessarily reflect the prevailing attitude of society towards disease. The changing view of bioarchaeology towards a 'social bioarchaeology' (Agarwal and Glencross, 2011) provides many opportunities to better understand not only disease in the past, but also the experience of disease by both those infected and society at large.

\section{Acknowledgements}

The author thanks Dr. Treena Swanston, supervising professor, for her encouragement and support. 


\section{References}

Agarwal SC, Glencross BA. 2011. Building a social bioarchaeology. In: Agarwal SC, Glencross BA, editors. Social Bioarchaeology. Chichester: Wiley-Blackwell. p 1-11.

Aufderheide AC, Rodríguez-Martin, C. 1998. The Cambridge Encyclopedia of Human Paleopathology. Cambridge: Cambridge University Press.

Baker BJ, Bolhofner KL. 2014. Biological and social implications of a medieval burial from Cyprus for understanding leprosy in the past. International Journal of Paleopathology 4:17-24.

Blau S, Yagodin V. 2005. Osteoarchaeological evidence for leprosy from Western Central Asia. American Journal of Physical Anthropology 126:150-158.

Brenner E. 2010. Recent perspectives on leprosy in medieval Western Europe. History Compass 8(5):388-406.

Conrad P, Barker KK. 2010. The social construction of illness: key insights and policy implications. Journal of Health and Social Behaviour 51:67-79.

Corrigan PW, Fong MWM. 2014. Competing perspectives on erasing the stigma of illness: What says the dodo bird? Social Science \& Medicine 103:110-117.

Craig E, Craig G. 2011. The diagnosis and context of a facial deformity from an Anglo-Saxon cemetery at Spofforth, North Yorkshire. International Journal of Osteoarchaeology 23:631-639.

Crawford S. 2010. Differentiation in the later Anglo-Saxon burial ritual on the basis of mental or physical impairment: a documentary perspective. In: Buckberry J, Cherryson A, editors. Burial in Later Anglo-Saxon England c. 650-1100 AD. Oxford: Oxbow Books. p 93-102.

De Groot R, van Brakel W, de Vries, HJC. 2011. Social implications of leprosy in the Netherlands - stigma among ex-leprosy patients in a non-endemic setting. Leprosy Review 82:168-177.

Goffman E. 1963. Stigma: Notes on the management of spoiled identity. Englewood Cliffs: Prentice-Hall.

Hadley DM. 2010. Burying the socially and physically distinctive in later Anglo-Saxon England. In: Buckberry J, Cherryson A, editors. Burial in Later Anglo-Saxon England c. 650-1100 AD. Oxford: Oxbow Books. p 103-115.
Hubert J. 2000. Introduction: the complexity of boundedness and exclusion. In: Hubert, J, editor. Madness, Disability, and Social Exclusion: The archaeology and anthropology of 'difference'. London: Routledge. p 1-8.

Hyland J. 2000. Leprosy and social exclusion in Nepal: the continuing conflict between medical and socio-cultural beliefs and practices. In: Hubert J, editor. Madness, Disability, and Social Exclusion: The archaeology and anthropology of 'difference'. London: Routledge. p 168-179.

Klaus HD, Ortner DJ. 2014. Treponemal infection in Peru's Early Colonial period: A case of complex lesion patterning and unusual funerary treatment. International Journal of Paleopathology 4:25-36.

Linderholm A, Kjellström A. 2011. Stable isotope analysis of a medieval skeletal sample indicative of systemic disease from Sigtuna Sweden. Journal of Archaeological Science 38:925-933.

Little LM, Papadopoulos JK. 1998. A social outcast in early Iron Age Athens. Hesparia: the Journal of the American School of Classical Studies at Athens 67(4):3775-404.

Martseller SJ, Torres-Rouff C, Knudson KJ. 2011. PreColumbian Andean sickness ideology and the social experience of leishmaniasis: A contextualized analysis of bioarchaeological and paleopathological data from San Pedro de Atacama, Chile. International Journal of Paleopathology 1:24-34.

Papadopoulos JK. 2000. Skeletons in wells: Towards and archaeology of exclusion in the ancient Greek world. In: Hubert J, editor. Madness, Disability, and Social Exclusion: The archaeology and anthropology of 'difference'. London: Routledge. p 96-118.

Pescosolido BA, Martin JK, Lang A, Olafsdottir S. 2008. Rethinking theoretical approaches to stigma: A Framework Integrating Normative Influences on Stigma (FINIS). Social Science \& Medicine 67:431-440.

Phelan JC, Link BG, Dovidio JF. 2008. Stigma and prejudice: One animal or two? Social Science \&Medicine 67:358-367.

Reidpath DD, Chan KY, Gifford SM, Allotey P. 2005. 'He hath the French pox': stigma, social value and social exclusion. Sociology of Health \& Illness 27(4):468-489.

Roberts CA. 2000. Did they take sugar? The use of skeletal evidence in the study of disability in past populations. In: Hubert J, editor. Madness, Disability, and Social Exclusion: The archaeology and anthropology of 'difference'. London: Routledge. p 46-59. 
Roberts CA. 2011. The bioarchaeology of leprosy and tuberculosis. In: Agarwal, SC, Glencross, BA, editors. Social Bioarchaeology. Chichester: Wiley-Blackwell. p 252-281.

Roffey S. 2012. Medieval leper hospitals in England: an archaeological perspective. Medieval Archaeology 56:203-

233.

Roffey S, Tucker K. 2012. A contextual study of the medieval hospital and cemetery of St Mary Magdalen, Winchester, England. International Journal of

Paleopathology 2:170-180.

Suzuki K, Saso A, Hoshino K, Sakurai J, Tanigawa K, Luo Y, Ishido Y, Mori S, Hirata K, Ishii N. 2014. Paleopathological evidence and detection of Mycobacterium leprae DNA from archaeological skeletal remains of Nabe-kaburi (headcovered with iron pots) burials in Japan. PLoS ONE 9(2): e88356. doi:10.1371/journal.pone.0088356.

Walker D. 2009. The treatment of leprosy in 19th-century London: a case study from St Marylebone cemetery. International Journal of Osteoarchaeology 19:364-374.

Wood JW, Milner GR, Harpending HC, Weiss KM, Cohen MN, Eisenberg LE, Hutchinson DL, Jankauskas R, Česnys G, Katzenberg MA, Lukacs JR, McGrath JW, Abella Roth E, Ubelaker DH, Wilkinson RG. 1992. The osteological paradox: problems of inferring prehistoric health from skeletal samples. Current Anthropology 33(4):343-370. 
